\title{
Nanomaterials and Their Effects on Health
}

\author{
Nanomalzemeler ve Sağlık Etkileri
}

\begin{abstract}
(D) Gülden Sarı1, (D) Birgül Piyal2 Ankara, Turkey

${ }^{2}$ Ankara University School of Medicine, Department of Public Health, Ankara, Turkey
\end{abstract}

1University of Health Sciences, Atatürk Chest Diseases and Thoracic Surgery Training and Research Hospital, Department of Occupational Medicine, öz

Pek çok potansiyel uygulama içeren nanoteknoloji, geleceğin teknolojisi ve 21. yüzyılın endüstriyel devrimi olarak nitelenmektedir. Nanoteknolojinin etkisi özellikle kimyasallar, ilaç ve kişisel bakım ürünleri için kullanılan nanomalzemelerde görülmektedir. Nano-ölçekli boyutu, geniş yüzey alanı ve yüzey aktivitesi gibi özellikler nanomalzemeleri çok fazla uygulama için ilgi çekici kılar. Günümüzde 1600'den fazla nanoboyutlu ürünün piyasada bulunduğu ve 2020 yılına kadar altı milyondan fazla çalıșanın mühendislik ürünü nanopartiküllere maruz kalacağı tahmin edilmektedir.

Küçülen parçacık boyutuyla paralel olarak malzemenin fiziksel, kimyasal ve toksikolojik özelliklerinde gözlenen değişiklikler nedeniyle nanopartiküllerin, biyolojik sistemler üzerine olumsuz etkilere neden olabileceği öngörülmektedir. Bununla birlikte, nanoteknolojinin göreli yeniliği nedeniyle, insanların nanopartiküllere maruziyet yolları ve nanopartiküllerin olası olumsuz sağlık etkileri hakkında bilgi eksikliği vardır. Mühendislik ürünü nanopartiküllere uzun süreli maruziyetin, insan sağ|ığı üzerine etkileri hakkındaki bilgi birikimi, in vitro çalıșmalar, in vivo hayvan çalıșmaları ve sınırlı sayıdaki insan maruziyet çalıșmalarına dayanmaktadır. Ülkemizde ise bu alanda yapılmış çalıșma bulunmamaktadır. Yakın zamanda ülkemizde de üretim artışı beklenen nanopartiküllerin sağlık etkilerinin daha iyi anlașılması, nanomalzemelerin güvenli kullanımı için, ele alınması gereken bilimsel bir zorunluluktur. Bu nedenle makalede güncel bilgiler ışı̆̆ında nanopartiküllerin insan sağlığı üzerine etkilerinin değerlendirilmesi ve böylece gelişebilecek tehlikelere dikkat çekmek amaçlanmıștır.

Anahtar Kelimeler: Nanomalzeme, nanoteknoloji, nanopartikül, sağlık etkileri

\section{Introduction}

Nanotechnology, a rapidly growing science that integrates engineering with biology, chemistry, and physics, is regarded by scientists as the industrial revolution of the $21^{\text {st }}$ century (1). When the dimensions of solid material are reduced to nanometer (nm) dimensions, their physical and chemical properties change. In order to take advantage of these features, we still lack serious information about the health effects of nanomaterials (NMs), which have been increasing in production in recent years (2).
Address for Correspondence/Yazıșma Adresi: Gülden Sarı MD, University of Health Sciences, Atatürk Chest Diseases and Thoracic Surgery Training and Research Hospital, Department of Occupational Medicine, Ankara, Turkey Phone: +90 5512323018 E-mail: drguldensari@gmail.com ORCID ID: orcid.org/0000-0003-1098-4405

Cite this article as/Atıf: Sarı G, Piyal B. Nanomaterials and Their Effects on Health İstanbul Med J 2019; 20(6): 497-501.
Received/Geliș Tarihi: 26.07 .2018 Accepted/Kabul Tarihi: 24.12.2018 
NMs are potentially useful nanoscale materials with unique properties. The International Organization for Standardization defines the term "NM" as "material with any external dimension in the nanoscale or having internal structure or surface structure in the nanoscale". One nm is defined as the one billionth of a meter, and "nanoscale" is used to express length range approximately from $1 \mathrm{~nm}$ to $100 \mathrm{~nm}$ (3).

Properties such as nanoscale size, large surface area, and surface activity make NMs interesting for many applications (4). In a study conducted in 2011, the number of NMs produced as a consumer product by 24 countries worldwide was found to increase from 212 to 1317 (5). It is estimated that more than 1600 nanoscale products are on the market today, and more than 6 million employees will be exposed to engineered nanoparticles (NP) by 2020 (6).

NMs are used in many areas such as computer chip technology, automotive catalytic converters, air and space vehicles, food, cosmetics (lipstick, sunscreens, anti-aging creams), dental prostheses and orthopedic implants $(7,8)$. There are more than 800 consumer products with different NM types. It is thought that a person consumes an average of 1012 NPs per day in a standard diet due to food additives (7).

In addition to consumer products, nanoscale molecules are also used in the drug transport system as nanotransporters. Nanotransporter systems have been developed to provide advantages such as reducing drug degradation and loss, preventing possible side effects, increasing drug biocompatibility, and being able to transport the drug in various regions in a controlled manner. These drug transport systems are divided into various classes, such as micelles, dendrimers, liposomes, NPs, and carbon nanotubes (CNT) $(9,10)$. Each has advantages and disadvantages. In the future, it is thought that the release and effect of drugs will happen via nanotransporters with "compliance and time" adjustment through controlling toxicity and regional effects by clinicians and researchers (11). However, since most clinical research reports for nanomedicine products focus mainly on the therapeutic efficacy of drugs, human biosecurity information is limited. In order to evaluate the human biosafety of nanomedicine products in clinical studies, it has been reported that a standardized test battery should be developed, including all indices of blood chemistry, carcinogenic, teratogenic, mutagenic toxicities and immune, nervous and reproductive systems (12).

NMs are grouped according to their size, morphology, production methods, and compositions. Nanostructures are divided into three according to size: a) One-dimensional nanostructures, commonly referred to as thin films, are technologies used in computer chips, antireflective coatings and sunglasses, b) two-dimensional nanostructures are nanowires and CNT used in separation and filtration technologies, c) three-dimensional nanostructures include perforated structures, colloids and quantum structures in atomic structure (13). NMs can be a pipe, rod, wire, or sphere according to their morphological structures. Depending on their source, they can be categorized, as engineered NPs and incidental NPs. Engineered NPs are particles produced to use nanometer-specific size-dependent properties (e.g., conductivity, spectral properties, biological distribution). Incidental NPs are defined as NPs that are either formed from anthropogenic sources (e.g., cigarette smoke, diesel fuel exhausts, industrial by-products) or naturally (e.g., marine spray, volcanic ash). Engineered NMs, including NP and nanofibers, are divided into four classes according to compounds: a) carbon-based materials (CNT, graphene, fullerene), b) metal-based materials (quantum dots, nanosilver, nanogold, titanium dioxide), c) dendrimers (nanoscale polymers) and d) composites (7).

\section{Clinical and Research Effects}

\section{Nanoparticle Exposure}

In addition to occupational exposure to NPs, direct human exposure with medical applications, and air pollution in the environment is a significant concern (14). NPs are taken into the human body through various exposure routes such as respiration, skin, and gastrointestinal tract during the production and consumption processes (15). The size of the nanostructures is very small, and their mass is relatively light. Therefore, especially in the working environment, the main entry route for NP is the respiratory system $(15,16)$. The size of the airborne particles reaching the airways affects the depth of the airways through which the particles can enter and their target organs (2). The primary deposition site of the NP, which is several tens of nanometers in size, is the alveolar area. From the NP reaching the alveoli, those within a range of several $\mathrm{nm}$ may reach the systemic circulation through the alveolar wall (17). Thus, they are translocated into secondary organs such as the liver, spleen, and kidney (18). It is estimated that the translocation of the inhaled NP into the circulation and secondary organs is less than $1 \%$ of the total mass-based amount. However, this rate is based on estimates from animal studies, and there is a lack of information on the biokinetics of inhaled NP and its long-term effects on humans (19).

Dermal exposure may occur during the application of topical creams and other drug treatments or accidental exposure (20). However, there are controversial data about the dermal absorption of NP. In contrast to studies reporting that NP cannot penetrate the dermis, Oberdörster et al. (21) demonstrated the penetration of various NPs in the dermis and translocation into the systemic circulation through the lymphatic system and regional lymph.

NPs may also enter the body indirectly after mucociliary clearance in the nasal region or directly through the gastrointestinal tract as a result of food, water, cosmetics, and drug consumption $(20,21)$. Without dosimetry and particle kinetics data, it is currently difficult to accurately assess the potential toxicity of foodborne NMs. Besides the direct effects of foodborne NMs, chronic NP exposure is thought to play a role in the development of inflammatory diseases with the potential to disrupt the normal microbiota balance in the gastrointestinal tract (22).

Limited to engineered materials, injections, and implants are also possible routes of exposure. Intravenous and oral administration has a faster systemic effect compared to other routes (23). Since these particles can easily pass into the circulatory system, they can reach the lymph and nervous system and reach many organs, including the brain (24). Also, injected NPs are rapidly absorbed by the liver and kidneys from the circulatory system (18). 


\section{The Effects of Nanoparticles on Health}

The health effects of NPs may vary depending on the number of physicochemical properties such as size, shape, surface properties, composition, solubility, aggregation/agglomeration, and the presence of mutagens and transition metals in the particles (25). Many engineered NPs have increased surface reactivity and, therefore, may cause local damage by inducing inflammation at the site of accumulation and the formation of reactive oxygen species (ROS) $(26,27)$. NP-induced ROS plays a crucial role in cell and tissue toxicity (28). Overproduction of ROS can trigger oxidative stress, which causes the cells to fail normal physiological redox reactions; thus, it leads to DNA damage, deterioration in cell signaling, changes in cell motility, cytotoxicity, apoptosis and the onset of cancer (29).

ROS are associated with different stages of carcinogenesis, including epigenetic changes, DNA damage, and protein and lipid changes (29). Metal-based NPs, especially silver, gold, and titanium, are essential for ROS production and genetic damage (30). In a recent study, workers with occupational exposure to metal oxide NMs in 14 factories producing and using NMs in Taiwan were evaluated for the first time for epigenetic alteration (methylation) and oxidative DNA damage. In this study, oxidative stress biomarkers and DNA methylation of 87 employees with exposure to metal oxide NMs (titanium dioxide, silicon dioxide, and indium dioxide) and 43 employees with no exposure were compared, and exposure to metal oxide NMs has been shown to cause methylation, oxidative damage to DNA, and lipid peroxidation (31).

It is vital to assess genotoxicity to protect employees from the potentially harmful effects of engineered NPs. Since many commonly used genotoxicity tests are adapted for soluble chemicals rather than particulates, genotoxicity test results for NPs are skeptical (4). However, some in vitro and in vivo studies have provided useful information on the relationship between NP exposure and genotoxicity in the working environment (32). In the study of Lindberg et al. (33), it was shown that genotoxic changes occurred in pulmonary epithelial cell culture with low doses of carbon CNT and graphite nanofiber exposure. Subsequently, in Lindberg et al. (33) study, human lymphocyte cells were exposed to singlewalled CNT (SWCNT), and multi-walled CNT (MWCNT) in low and moderate doses $(6.25-300 / \mathrm{g} / \mathrm{mL})$ and this finding was confirmed by demonstrating chromosomal abnormalities (33). The point that should be considered in these studies is that genotoxic effects have been observed at the exposure levels expected in occupational environments (2).

From the experimental results, a study was conducted to evaluate potential genotoxic effects of NMs in humans and found significant changes in the messenger RNA and non-coding expression profiles in the sera of workers (eight workers) exposed to MWCNT for more than six months compared to those without exposure (seven workers). Also, described pathways and signaling networks have revealed the potential of MWCNT to produce carcinogenic results in humans as well as pulmonary and cardiovascular effects, similar to rodents previously exposed to MWCNT (34).

As the size of the particles reaching the airways becomes smaller, the depth of the airways through which the particles can enter increases, and thus their effects on the target organs change. In studies evaluating the relationship between particle size and lung inflammation and toxicity, engineered NPs and coarse particles were compared, and a higher rate of lung inflammation and toxicity response to NPs was observed $(35,36)$.

NPs are thought to cause pathological changes in the lung regardless of dose. In two independent studies, mice exposed to SWCNT at doses of 3.3-16.6 mg/kg and 10-40 ug/mouse have developed a strong acute inflammatory response, with the development of pulmonary fibrosis leading to impaired pulmonary function $(37,38)$.

Although we have limited data on engineered NPs, many epidemiological studies have shown a direct coherence between the increased amounts of incidental NP produced in indoor air and the increased adverse health effects associated with cardiovascular disease. There is a strong link that supports the relationship between inflammation and coronary heart disease because inflammation has been proven to be directly associated with atherosclerosis (39). Data from human studies support the link between PM air pollution and the development of cardiac responses leading to atherosclerosis (40). In the review of epidemiological studies, Delfino et al. (41) have clearly demonstrated pathophysiological changes that induce cardiovascular diseases by exposure to ultra-fine particles. In a recent animal study, titanium NPs have been shown to affect ventricular cardiomyocytes besides indirect inflammatory effects directly. In rodents exposed to intratracheal titanium dioxide NPs, shortened repolarization time, increased cardiac conduction and excitability rate, and ventricular arrhythmia were observed (42).

Although there are few epidemiological studies showing the direct effect of engineered NPs on human health in the literature, the known health effects of NMs in the guideline published by WHO in 2017 including all the studies conducted were divided into nine categories: Acute toxicity, skin corrosion/irritation, eye damage/irritation, respiratory and skin sensitization, genotoxicity, carcinogenicity, reproductive system toxicity, specific target organ toxicity following single exposure and specific target organ toxicity following repeated exposure. In the guideline (19), the effects of 11 NMs on human health were for summarized as follows:

Fullerene: There is evidence that it does not cause acute toxicity, skin, eye, respiratory damage, genotoxicity, and specific target organ toxicity after repeated exposure, but data are lacking for other hazard categories.

SWCNT: There is evidence of genotoxicity and specific target organ toxicity after repeated exposure (low level of evidence). There is evidence that it does not cause acute toxicity, eye and skin damage, and respiratory/skin sensitization. There is no data showing that it causes reproductive system toxicity and specific target organ toxicity after a single exposure. It has been classed as group 3 (those that cannot be classified as carcinogenic in humans) by the International Agency for Research on Cancer (IARC).

MWCNT: There is evidence of eye damage (strong grade of evidence), genotoxicity (strong grade of evidence), carcinogenicity (moderate grade of evidence), and specific target organ toxicity following repeated exposure (moderate grade of evidence). There is evidence that it does not cause acute toxicity, skin damage, respiratory/skin sensitization, and reproductive system toxicity. There is no evidence of specific target organ toxicity following a single exposure. MWCNT-7 has been classed as 
group 2B (possibly carcinogenic in humans) by IARC and other MWCNTs as group 3 (those that cannot be classified as carcinogenic in humans).

Silver NPs: There is evidence of respiratory/skin sensitization (moderate grade of evidence), and specific target organ toxicity following repeated inhalation and oral exposure (strong grade of evidence). There is evidence that they do not cause acute toxicity, eye damage, and genotoxicity. There is no evidence of carcinogenicity and specific target organ toxicity following a single exposure.

Gold NPs: There is evidence of specific target organ toxicity following repeated inhalation exposure (strong grade of evidence). There is no data for other classes.

Silicon dioxide: There is evidence of specific target organ toxicity following repeated inhalation exposure (strong grade of evidence). There is evidence that it does not cause acute toxicity, eye and skin damage, respiratory and skin sensitization, genotoxicity, and reproductive system toxicity. There is no data for carcinogenicity and specific target organ toxicity following a single exposure.

Titanium dioxide: There is evidence of reproductive system toxicity (moderate grade of evidence) and specific target organ toxicity (strong grade of evidence) following repeated inhalation exposure. There is evidence that it does not cause acute toxicity, skin and eye damage, respiratory and skin sensitization, and genotoxicity. There is no data for specific target organ toxicity following a single exposure. It has been classed as group 2B (possibly carcinogenic in humans) by IARC.

Cerium dioxide: There is evidence of specific target organ toxicity following repeated inhalation exposure (moderate grade of evidence). There is evidence that it does not cause acute toxicity. There is no data available for other hazard classes.

Dendrimers and nanoclays: There is no data on hazard classes.

Zinc oxide: There is evidence of specific target organ toxicity following repeated inhalation exposure (moderate grade of evidence). There is evidence that they do not cause acute toxicity, skin and eye damage, genotoxicity, and reproductive system toxicity. There is no data on respiratory/skin sensitization, carcinogenicity, and specific target organ toxicity following a single exposure.

As a result, it is emphasized in the guideline that prudence should be taken against engineered NPs that we do not yet know the health risks and that the proactive approach should minimize the exposure of workers (19).

\section{Conclusion}

Features such as nanoscale size, large surface area, and surface activity make NMs appealing for many applications. Therefore, nanoscale materials are increasingly used in many areas of daily life, such as industry, science, pharmacy, medicine, electronics, communications, and consumer products. Although it is predicted that NPs may cause adverse effects on biological systems due to the observed changes in the physical, chemical and toxicological properties of the material in parallel with the decreasing particle size, unfortunately, there is still a lack of data about the ways people are exposed to NP and the possible negative health effects of NPs. Toxicological assessment of these new materials is a scientific necessity that needs to be addressed in order to recognize risks, avoid potential hazards, and safe use of NPs. Although humans have been exposed to unwanted NPs for the long-term due to combustion processes, the recent increase in engineered production of NMs requires further investigation into potential toxicity and adverse health effects after exposure. Since the potential health effects of newly engineered NMs have not been sufficiently tested, a prudent approach should be adopted until they reach reliable results.

\section{Ethics}

Peer-review: Externally peer-reviewed.

Author Contributions: Concept - G.S., B.P.; Design - G.S., B.P.; Supervision - G.S., B.P.; Analysis and/or Interpretation - G.S., B.P.; Literature Search G.S., B.P.; Writing Manuscript - G.S.; Critical Review - G.S., B.P.

Conflict of Interest: No conflict of interest was declared by the authors. Financial Disclosure: The authors declared that this study received no financial support.

\section{References}

1. Schmid G, Decker M, Ernst H, Fuchs H, Grünwald W, Grunwald A, et al. Small dimensions and material properties. A Definition of Nanotechnology. Europaische Akademie 2003; 11.

2. Pietroiusti A, Stockmann-Juvala H, Lucaroni F, Savolainen K. Nanomaterial exposure, toxicity, and impact on human health. WIRES Nanomed Nanobiotechnol 2018: e1513.

3. BSI B. Vocabulary-Nanoparticles. PAS 71: 2005. 2005.

4. Landsiedel R, Kapp MD, Schulz M, Wiench K, Oesch F. Genotoxicity investigations on nanomaterials: methods, preparation and characterization of test material, potential artifacts and limitations-many questions, some answers. Mutat Res 2009; 681: 241-58.

5. Roco MC. International perspective on government nanotechnology funding in 2005. J Nanopart Res 2005; 7: 707-12.

6. Roco MC. The long view of nanotechnology development: the National Nanotechnology Initiative at 10 years. Journal of Nanoparticle Research 2011; 13: $427-45$.

7. Singh N, Manshian B, Jenkins GJ, Griffiths SM, Williams PM, Maffeis TG, et al. NanoGenotoxicology: the DNA damaging potential of engineered nanomaterials. Biomaterials 2009; 30: 3891-914.

8. Brown C, Fisher J, Ingham E. Biological effects of clinically relevant wear particles from metal-on-metal hip prostheses. Proc Inst Mech Eng H 2006; 220: 355-69

9. Estanqueiro M, Amaral MH, Conceição J, Lobo JMS. Nanotechnological carriers for cancer chemotherapy: the state of the art. Colloids Surf B Biointerfaces 2015; 126: 631-48.

10. Madani SY, Naderi N, Dissanayake O, Tan A, Seifalian AM. A new era of cancer treatment: carbon nanotubes as drug delivery tools. Int J Nanomedicine 2011; 6: 2963-79.

11. Turgut DC, Ak G, Dağ I, Soyocak A, Dikmen G, Dal A, et al. Drug carrier nanosystems in malignant pleural mesothelioma. Tuberk Toraks 2016; 64 60-8.

12. Su H, Wang Y, Gu Y, Bowman L, Zhao J, Ding M. Potential applications and human biosafety of nanomaterials used in nanomedicine. J Appl Toxicol 2018; 38: 3-24. 
13. Buzea C, Blandino I, Robbie K. Nanomaterials and nanoparticles: sources and toxicity. Biointerphases 2007; 2: MR17-71.

14. Gwinn MR, Vallyathan V. Nanoparticles: health effects-pros and cons. Environ Health Perspect 2006; 114: 1818-25.

15. Savolainen K, Alenius H, Norppa H, Pylkkänen L, Tuomi T, Kasper G. Risk assessment of engineered nanomaterials and nanotechnologies-a review. Toxicology 2010; 269: 92-104.

16. Borm PJ, Robbins D, Haubold S, Kuhlbusch T, Fissan H, Donaldson K, et al. The potential risks of nanomaterials: a review carried out for ECETOC. Part Fibre Toxicol 2006; 3: 11.

17. Kreyling WG, Semmler-Behnke M, Seitz J, Scymczak W, Wenk A, Mayer P, et al. Size dependence of the translocation of inhaled iridium and carbon nanoparticle aggregates from the lung of rats to the blood and secondary target organs. Inhal Toxicol 2009; 21 Suppl 1: 55-60.

18. Wu T, Tang M. Review of the effects of manufactured nanoparticles on mammalian target organs. J Appl Toxicol 2018; 38: 25-40

19. Organisation WH. WHO guidelines on protecting workers from potential risks of manufactured nanomaterials. 2017.

20. Hagens WI, Oomen AG, de Jong WH, Cassee FR, Sips AJ. What do we (need to) know about the kinetic properties of nanoparticles in the body? Regul Toxicol Pharmacol 2007; 49: 217-29.

21. Oberdörster G, Oberdörster E, Oberdörster J. Nanotoxicology: an emerging discipline evolving from studies of ultrafine particles. Environ Health Perspect 2005; 113: 823-39.

22. Bouwmeester $\mathrm{H}$, van der Zande $\mathrm{M}$, Jepson $\mathrm{MA}$. Effects of food-borne nanomaterials on gastrointestinal tissues and microbiota. Wiley Interdiscip Rev Nanomed Nanobiotechnol 2018; 10

23. Yildirimer L, Thanh NT, Loizidou M, Seifalian AM. Toxicology and clinical potential of nanoparticles. Nano Today 2011; 6: 585-607.

24. Arora S, Rajwade JM, Paknikar KM. Nanotoxicology and in vitro studies: the need of the hour. Toxicol Appl Pharmacol 2012; 258: 151-65.

25. Kisin ER, Murray AR, Keane MJ, Shi X-C, Schwegler-Berry D, Gorelik O, et al. Single-walled carbon nanotubes: geno-and cytotoxic effects in lung fibroblast V79 cells. J Toxicol Environ Health A 2007; 70: 2071-9.

26. Donaldson K, Schinwald A, Murphy F, Cho W-S, Duffin R, Tran L, et al. The biologically effective dose in inhalation nanotoxicology. Acc Chem Res 2013; 46: 723-32.

27. Mercer RR, Scabilloni JF, Hubbs AF, Battelli LA, McKinney W, Friend S, et al. Distribution and fibrotic response following inhalation exposure to multiwalled carbon nanotubes. Part Fibre Toxicol 2013; 10: 33

28. Du H, Zhu X, Fan C, Xu S, Wang Y, Zhou Y. Oxidative damage and OGG1 expression induced by a combined effect of titanium dioxide nanoparticles and lead acetate in human hepatocytes. Environ Toxicol 2012; 27: 590-7.
29. Fu PP, Xia Q, Hwang H-M, Ray PC, Yu H. Mechanisms of nanotoxicity: generation of reactive oxygen species. J Food Drug Anal 2014; 22: 64-75.

30. Aydın A, Sipahi H, Charehsaz M. Nanoparticles toxicity and their routes of exposures. Pak J Pharm Sci 2012; 25: 477-91.

31. Liou S-H, Wu W-T, Liao H-Y, Chen C-Y, Tsai C-Y, Jung W-T, et al. Global DNA methylation and oxidative stress biomarkers in workers exposed to metal oxide nanoparticles. J Hazard Mater 2017; 331: 329-35.

32. Lindberg HK, Falck GC-M, Singh R, Suhonen S, Järventaus H, Vanhala E, et al. Genotoxicity of short single-wall and multi-wall carbon nanotubes in human bronchial epithelial and mesothelial cells in vitro. Toxicology 2013; 313: 24 37.

33. Lindberg HK, Falck GC-M, Suhonen S, Vippola M, Vanhala E, Catalán J, et al Genotoxicity of nanomaterials: DNA damage and micronuclei induced by carbon nanotubes and graphite nanofibres in human bronchial epithelial cells in vitro. Toxicol Lett 2009; 186: 166-73.

34. Shvedova AA, Yanamala N, Kisin ER, Khailullin TO, Birch ME, Fatkhutdinova LM. Integrated analysis of dysregulated ncRNA and mRNA expression profiles in humans exposed to carbon nanotubes. PLoS One 2016; 11: e0150628.

35. Brown DM, Wilson MR, MacNee W, Stone V, Donaldson K. Size-dependent proinflammatory effects of ultrafine polystyrene particles: a role for surface area and oxidative stress in the enhanced activity of ultrafines. Toxicol Appl Pharmacol 2001; 175: 191-9.

36. Donaldson K, Tran CL. Inflammation caused by particles and fibers. Inhal Toxicol 2002; 14: 5-27

37. Lam C-W, James JT, McCluskey R, Hunter RL. Pulmonary toxicity of singlewall carbon nanotubes in mice 7 and 90 days after intratracheal instillation. Toxicol Sci 2004; 77: 126-34

38. Shvedova AA, Kisin ER, Mercer R, Murray AR, Johnson VJ, Potapovich Al, et al. Unusual inflammatory and fibrogenic pulmonary responses to single-walled carbon nanotubes in mice. Am J Physiol Lung Cell Mol Physiol 2005; 289: L698-708.

39. Sun Q, Wang A, Jin X, Natanzon A, Duquaine D, Brook RD, et al. Long-term air pollution exposure and acceleration of atherosclerosis and vascular inflammation in an animal model. JAMA 2005; 294: 3003-10.

40. Brook RD, Franklin B, Cascio W, Hong Y, Howard G, Lipsett M, et al. Air pollution and cardiovascular disease. Circulation 2004; 109: 2655-71.

41. Delfino RJ, Sioutas C, Malik S. Potential role of ultrafine particles in associations between airborne particle mass and cardiovascular health. Environ Health Perspect 2005; 113: 934-46.

42. Savi M, Rossi S, Bocchi L, Gennaccaro L, Cacciani F, Perotti A, et al. Titanium dioxide nanoparticles promote arrhythmias via a direct interaction with rat cardiac tissue. Part Fibre Toxicol 2014; 11: 63 